\title{
FRACTIONAL REPLACEMENT OF BITUMEN WITH CRMB \& PMB AND COMPARING THEIR PERFORMANCE -A REVIEW
}

\author{
N. Satheeshkanna, Manoj Kumar Sharma, Upadhyay Lohit \\ E-Mail Id: n.satheeshkanna@anandice.ac.in
}

Department of Civil Engineering, Anand International College of Engineering, Jaipur, Rajasthan (India)

\begin{abstract}
The project aims at the utilization of waste rubber or plastics in road construction as these substances are very hazardous for health and deteriorate the environmental conditions at large scale. It was estimated that there was a rise of 2.85 million tones rise in diseases on human health due to these waste products. The project aims to study the performance of different materials which may help in utilizing the waste to improve the quality of roads and make them stable, durable and long lasting. In this study, the bitumen is partially replaced with PMB \& CRMB and their performance evaluation were carried out and the results were compared. It was shown that the utilization of CRMB \& PMB proved to be more efficient and stable.
\end{abstract}

\section{INTRODUCTION}

Road network is the mode of transportation which serves as the feeder system as it is the nearest to the people. So the roads are to be maintained in good condition. The quality of roads depends on materials used for construction [1]. Due to urbanization, industrialization and large increase of populations, accompanied with uplift in the standard of living, road vehicle numbers have increased dramatically which, consequently, has resulted in a lot of end-of-use tires every year. The estimated number of tires manufactured in the world per annum is about 1.5 billon tires [2].

Keeping in mind the need for bulk use of these solid wastes in India, it was thought expedient to test these materials and to develop specifications to enhance the use of waste tyres and plastic materials in road making in which higher economic returns may be possible. The necessary specifications will be formulated and attempts are to be made to maximize the use of solid wastes in different layers of the road pavement [3].

Each year approximately millions of tires are added to stockpiles, landfills or illegal dumps across the United States. The estimated number of accumulated tires is slightly over half a million. The large number of tires accumulated over the years and currently being generated creates a disposal problem in the rural areas [2]. Nowa-days disposal of different wastes produced from different Industries is a great problem. These materials pose environmental pollution in the nearby locality because many of them are non-biodegradable. Also, cost of extracting good quality of natural material is increasing [4].

A common method to improve the quality of bitumen is by modifying the Engineering properties of bitumen by blending with organic synthetic polymers like rubber and plastics [5].

Post construction pavement performance studies are to be done for these waste materials for construction of low Volume roads with two major benefits [6]:

$>$ It will help clear valuable land of huge dumps of wastes.

$>$ It will also help to preserve the natural reserves of aggregates, thus protecting the environment. Rubber tyres are user friendly but not eco-friendly as they are non-biodegradable generally.

The main aim of this project is to be focus on using the available waste/recycled PMB \& CRMB present in abundant which can be used economically and conveniently. The use of these materials as a road construction proves eco-friendly, economical and use of plastic will also give strength in the sub-base course of the pavement [7].

It was observed that the penetration and ductility values of the modified bitumen decreased with the increase in proportion of the plastic additive. Therefore the life of the pavement surfacing using the modified bitumen is also expected to increase substantially in comparison to the use of ordinary bitumen [8].

CRMB- Crumb rubber is actually small pieces of waste tyre scrapped from light motor vehicles and whose disposal is a serious menace. The annual available capacity for procured tyres is retreading [9].

PMB- Plastic is material consisting of any of a wide range of synthetic or semi-synthetic organic compounds that are malleable and so can be molded into solid objects [10].

\section{METHODS}

\subsection{Experimental Program}

The Bituminous Concrete mix will be preparing using Marshall Stability Method of bitumen mix design. The BC will be prepared with conventional grades of Bitumen and adding various percentages of PMB and CRMB as mentioned below [10].

Table 2.1 Detail of Sample Constitution \& \% Constituents

\begin{tabular}{|c|c|c|c|}
\hline S. No. & $\begin{array}{c}\text { Sample } \\
\text { Preparation }\end{array}$ & Sample Constitution & $\begin{array}{c}\text { \% of Constituent by weight of } \\
\text { bitumen }\end{array}$ \\
\hline 1 & Wet Process & Bitumen Mix & - \\
\hline
\end{tabular}


ICRDET-2021, February 26-27, 2021, AICE, Jaipur, India

International Journal of Technical Research \& Science (Special Issue) ISSN No.:2454-2024 (online)

\begin{tabular}{|c|c|c|c|}
\hline 2 & Dry Process & Bitumen + PMB & PMB: $3 \%$ \\
& & & PMB: $6 \%$ \\
& & & PMB: $9 \%$ \\
\hline \multirow{2}{*}{3} & \multirow{2}{*}{ Wet Process } & Bitumen + CRMB & CRMB: $8 \%$ \\
& & & CRMB: $10 \%$ \\
& & CRMB: $12 \%$ \\
\hline
\end{tabular}

\subsection{Marshall Stability Test}

Before preparing the specimens for Marshall Test, it is required that following steps.

$>$ Material proposed for use the gradation requirements of the project specifications.

$>$ The blend combinations meet the gradation requirements of the project specifications.

$>$ Therefore use in density and voids analysis the pulse specific gravity of all aggregate used in the blend and the specific gravity of asphalt are determined.

After this, the other parameters like Unit Weight (gm/cc), Specific Gravity of mix (Gmm), Air Voids (\%), Voids in mineral aggregates (\%), Voids filled with bitumen (\%), etc. are calculated by derived formulas.

\subsection{Specimen Preparation}

According to IRC: $29-19881200 \mathrm{gm}$ of aggregates and filler is heated to a temperature of $175-190^{\circ} \mathrm{C}$. Bitumen is heated to a temperature of $121-125^{\circ} \mathrm{C}$ with the first trial percentage of bitumen (say 3.5 or $4 \%$ by weight of the mineral aggregates). The heated aggregates and bitumen are thoroughly mixed at a temperature of $154-160^{\circ} \mathrm{C}$. The mix is placed in a preheated mould and compacted by a rammer with 50 blows on either side at temperature of $138-149^{\circ} \mathrm{C}$. The weight of mixed aggregates taken for the preparation of the specimen may be suitably altered to obtain a compacted thickness of $63.5+/-3 \mathrm{~mm}$. Vary the bitumen content in the next trial by $+0: 5 \%$ and repeat the above procedure. Number of trials is predetermined.

Table 2.3 Marshal Mix Design Specification

\begin{tabular}{|c|l|c|}
\hline Sl.No. & \multicolumn{1}{|c|}{ Test Property } & Specified Value \\
\hline 1 & Marshall stability, kg & 340 (minimum) \\
\hline 2 & Flow value, 0.25 mm units & $8-17$ \\
\hline 3 & Percent air voids in the mix vv \% & $3-5$ \\
\hline 4 & Voids filled with bitumen VFB \% & $75-85$ \\
\hline
\end{tabular}

Then, Plot $\%$ of bitumen content on the X-axis and stability in $\mathrm{kg}$ on the Y-axis to get maximum Marshall Stability of the bitumen mix. A sample plot is given,

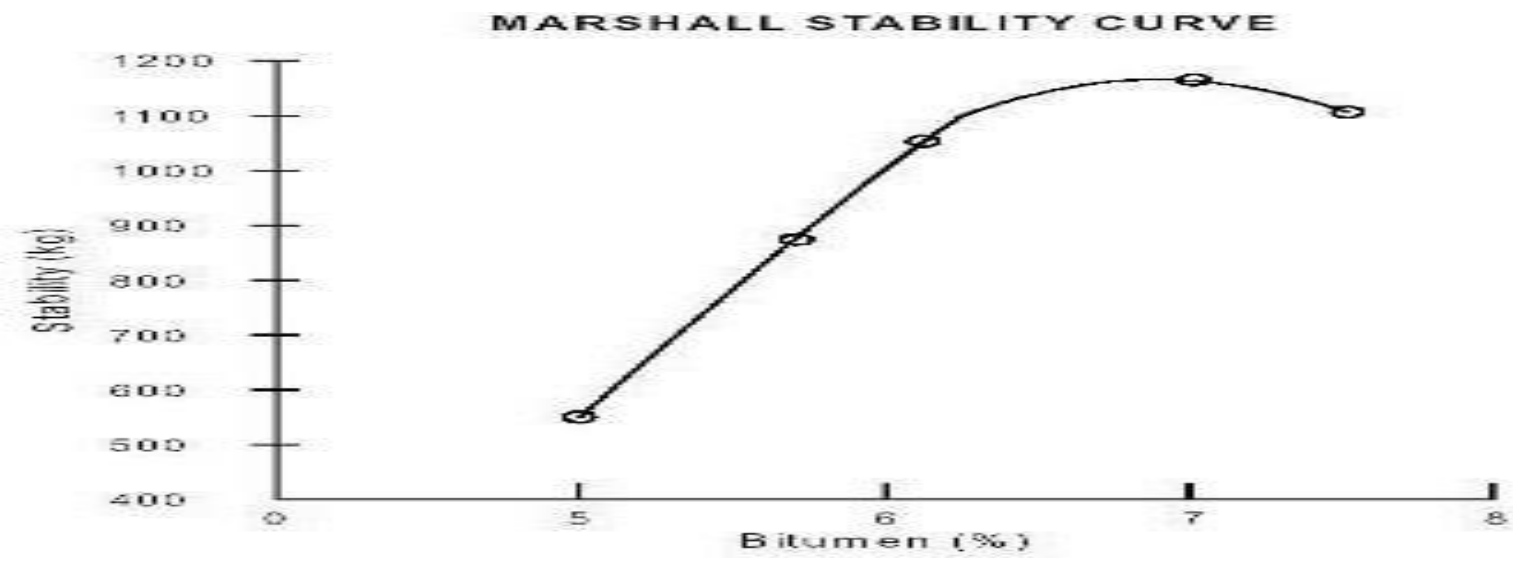

\subsection{Tests on Bitumen}

Table 2.4 Tests on Bitumen \& their Results

\begin{tabular}{|r|l|l|l|}
\hline $\begin{array}{r}\text { S. } \\
\text { No. }\end{array}$ & Laboratory Test & Reference & \multicolumn{1}{|c|}{ Inference } \\
\hline 1 & Penetration Test & IS: 1203-1978 & $\begin{array}{l}\text { Penetration Value: } 30 / 40,60 / 70,80 / 100 \text { (For Normal } \\
\text { Climatic Conditions) } \\
\text { Penetration Value: } 180 / 200 \text { (For colder Conditions) }\end{array}$ \\
\hline
\end{tabular}

DOI Number: https://doi.org/10.30780/specialissue-ICRDET-2021/005 
ICRDET-2021, February 26-27, 2021, AICE, Jaipur, India

International Journal of Technical Research \& Science (Special Issue) ISSN No.:2454-2024 (online)

\begin{tabular}{|c|c|c|c|c|}
\hline \multirow{7}{*}{2} & \multirow{7}{*}{ Ductility Test } & \multirow{7}{*}{ IS: $1208-1978$} & penetration grade & $\begin{array}{l}\text { Min. ductility value } \\
\text { (cms) }\end{array}$ \\
\hline & & & Assam Petroleum A25 & 5 \\
\hline & & & A35 & 10 \\
\hline & & & A45 & 12 \\
\hline & & & $\mathrm{A} 65, \mathrm{~A} 90$ and A200 & 15 \\
\hline & & & S35 & 50 \\
\hline & & & $\mathrm{S} 45, \mathrm{~S} 65$ and $\mathrm{S} 90$ & 75 \\
\hline 3 & Softening Point Test & IS: $1205-1978$ & \multicolumn{2}{|c|}{$\begin{array}{l}\text { Higher softening point indicates lower temperature } \\
\text { susceptibility }\end{array}$} \\
\hline 4 & Specific Gravity Test & IS: $1202-1978$ & \multicolumn{2}{|l|}{0.97 to 1.02} \\
\hline 5 & Viscosity Test & IS: $1206-1978$ & \multicolumn{2}{|c|}{$\begin{array}{l}\text { Orifice Size }-4 \mathrm{~mm}: \text { Viscus- } 25 \text { to } 250 \\
\text { Orifice Size }-10 \mathrm{~mm} \text { : Viscus-10 to } 140\end{array}$} \\
\hline 6 & Flash And Fire Point Test & IS: $1209-1978$ & \multicolumn{2}{|c|}{ minimum value of flash point $-175^{\circ} \mathrm{C}$} \\
\hline
\end{tabular}

\subsection{Tests on CRMB}

Table 2.5 Tests on CRMB \& their Results

\begin{tabular}{|c|l|c|}
\hline Sl. No. & Laboratory Test & Inference \\
\hline 1 & Penetration Test & Penetration Value: $60 / 70$ \\
\hline 2 & Ductility Test & $100 \mathrm{~cm}$ \\
\hline 3 & Softening Point Test & $48-50^{0} \mathrm{C}$ \\
\hline 4 & Specific Gravity Test & $1-1.15$ \\
\hline 5 & Flash And Fire Point Test & minimum value of flash point $-300-325^{\circ} \mathrm{C}$ \\
\hline
\end{tabular}

2.6 Tests on PMB

Table 2.6 Tests on PMB \& their Results

\begin{tabular}{|c|l|l|}
\hline Sl. No. & \multicolumn{1}{|c|}{ Laboratory Test } & Inference \\
\hline 1 & Penetration Test & Variation in 65 to $70 \mathrm{~mm}$ \\
\hline 2 & Ductility Test & Variation in 35 to $70 \mathrm{~cm}$ \\
\hline 3 & Softening Point Test & $120-150^{\circ} \mathrm{C}$ \\
\hline 4 & Specific Gravity Test & $0.91-1.4$ \\
\hline 5 & Flash And Fire Point Test & minimum value of flash point $-240-320^{\circ} \mathrm{C}$ \\
\hline
\end{tabular}

\subsection{Tests on Aggregates}

Table 2.6 Tests on Aggregates \& their Results

\begin{tabular}{|c|c|c|c|}
\hline Sl. No. & Laboratory Test & Reference & Inference \\
\hline 1 & Crushing test & IS: 2386 part-IV & $\begin{array}{l}<10-\text { Strong Aggregate } \\
>35-\text { Weak Aggregate }\end{array}$ \\
\hline 2 & Abrasion Test & IS: 2386 part IV & $\begin{array}{l}<40 \%-\text { WBM base course } \\
<35 \% \text { - Bituminous Concrete }\end{array}$ \\
\hline
\end{tabular}


ICRDET-2021, February 26-27, 2021, AICE, Jaipur, India

International Journal of Technical Research \& Science (Special Issue) ISSN No.:2454-2024 (online)

\begin{tabular}{|c|c|c|l|}
\hline 3 & Impact Test & IS: 2386 part IV & $\begin{array}{l}<30 \%-\text { Wearing Coarse } \\
<35 \%-\text { Bituminous Macadam } \\
=40 \%-\text { WBM }\end{array}$ \\
\hline 4 & $\begin{array}{c}\text { Shape Test } \\
\text { Flakiness Index } \\
\text { 2. Elongation Index }\end{array}$ & $\begin{array}{c}\text { IS: } 2386 \text { part-I } \\
\text { IS: } 2386 \text { part-I }\end{array}$ & $\begin{array}{l}\text { least dimension is }<0.6 \text { times their mean size } \\
\text { greatest dimension (length) is } 1.8 \text { times } \\
\text { their meandimension }\end{array}$ \\
\hline 5 & $\begin{array}{c}\text { Specific Gravity and } \\
\text { Water Absorption test }\end{array}$ & IS: 2386 part-III & $\begin{array}{l}\text { Specific Gravity: } 2.5 \text { to } 2.9 \\
\text { Water Absorption: } 0.1 \text { to } 2 \%\end{array}$ \\
\hline
\end{tabular}

\section{RESULTS \& DISCUSSIONS}

The use of Crumb Rubber in Flexible Pavements has a lot of advantages when compared to the disadvantages. The use of Warm mix bitumen has clearly shown that the cost can be significantly bought down by using CRMB \& PMB over conventional bitumen pavements has shown that the load carried by CRMB pavements is higher than that of the conventional bituminous pavements and by adding crumb rubber to the bituminous pavements the waste tires which are used as landfill can be significantly bought down.

Likewise CRMB \& PMB of Hot Mix Role in Flexible Pavements for a Sustainable Future. The fumes from hot mix asphalt are known to be potential health hazards, especially for the construction workers. Reduced temperature of the mix avoids this health hazard.

\section{CONCLUSION}

It can be seen that the modified bitumen showing better results compared to the normal bitumen. This method contributes for improved disposal of waste tyres and waste plastics. Decrease in penetration point, increases load - bearing capacity of the road. The Marshall Stability value is high hence increases life of the road. While using CRMB \& PMB, the melting point of bitumen will be increased. Waste tyre modified bituminous surface of road increases their life period especially the pavement requires low maintenance costs.

\section{ACKNOLEDGMENTS}

The author would like to extend her deepest gratitude and gratefulness to mentors for providing with the right ways of thinking and concepts of this research. The author wishes deeply thankful to all his friends for the encouragement which have been helpful in his research to attain the destination without any trouble.

\section{REFERENCES}

[1] Rokade S, Use of Waste Plastic and Waste Rubber Tyres in Flexible Highway Pavements, International Conference on Future Environment and Energy, (2012).

[2] Bekhiti, M., Trouzine, H., and Asroun, A., Properties of Waste Tire Rubber Powder, Engineering, Technology \& Applied Science Research, (2014).

[3] Khan, N., Nafees, A., Hussain, A., Zaidi, G., Osama, M., and Ghaffar, S., Exploring the Properties of Recycled Tyre Rubber for Flexible Asphalt Pavement, Journal of Basic \& Applied Sciences, (2017)

[4] Sarathy, V., Ravindraraj, J., and Kumar, D., Analysis of Properties in Bitumen and Asphalt with Partial Replacement of Rubber Tyres, International Journal Of Innovative Research \& Development, (2015).

[5] Mashaan, N., Ali, AH., Karim, MR., and Abdelaziz, M, An overview of crumb rubber modified asphalt, International Journal of the Physical Sciences, (2012).

[6] Raol, H., Parmar, A., Patel, D., and Jayswal, J., Effect Of The Use Of Crumb Rubber In Conventional Bitumen On The Marshall Stability Value, International Journal of Research in Engineering and Technology, (2014)

[7] Priyanka, M., Ganesh, PD., and Bhosale, S.M., Laboratory Evaluation of Usage of Waste Tyre Rubber in Bituminous Concrete, International Journal of Scientific and Research Publications, (2013).

[8] Baraiya, D., Use of Waste Rubber Tyres in Construction of Bituminous Road - An Overview, International Journal of Application or Innovation in Engineering \& Management, (2013).

[9] Deshmukh, H., and Kshirsagar, Y., Utilization of Rubber Waste in Construction of Flexible Pavement, International Journal of Advance Research and Development, (2017).

[10] Kumar, CP., and Shashishankar, Study of Crumb rubber for the partial replacement for bitumen or as an alternative material for bitumen, Applied Sciences, Engineering \& Technology, (2015). 